\title{
Correction to: Can the Welfare State Justify Restrictive Asylum Policies? A Critical Approach
}

\author{
Clara Sandelind ${ }^{1}$ \\ Published online: 29 April 2021 \\ (C) Springer Nature B.V. 2021
}

\section{Correction to: Ethical Theory and Moral Practice (2019, 22: 331-346) https://doi.org/10.1007/s10677-019-09989-3}

The original version of the article unfortunately contained a sentence with two typos on page 343:

'Östbring (2017: X) briefly considers some alternatives to asylum in Western states like Sweden, without discussing how these alternatives my square with the aims and motivations of refugees.'

The corrected sentence should read:

'Östbring (2017) briefly considers some alternatives to asylum in Western states like Sweden, without discussing how these alternatives may square with the aims and motivations of refugees.'

Publisher's Note Springer Nature remains neutral with regard to jurisdictional claims in published maps and institutional affiliations.

The online version of the original article can be found at https://doi.org/10.1007/s10677-019-09989-3

Clara Sandelind

clara.sandelind@manchester.ac.uk

1 The Department of Politics, The University of Sheffield, Elmfield, Northumberland Road, Sheffield S10 2TU, UK 